\title{
Daylighting in older people's housing: Barriers to compliance with current UK guidance
}

\author{
A Lewis MArch, PhD \\ Manchester Architecture Research Centre, School of Environment and Development, \\ University of Manchester, Manchester, UK
}

Short title: Barriers to daylighting

Received 1 August 2014; Revised 6 January 2015; Accepted

This work identified barriers to compliance with current UK guidance on daylighting in the design of extra-care housing which provides older occupants with self-contained dwellings and access to communal facilities and care. Secondary analysis was made of data from a survey of 165 dwellings in 23 extra-care housing schemes in England.

Semi-structured interviews were conducted with 20 people involved in the design of extra-care housing. Findings suggest that financial constraints limit the feasibility of providing dual aspect dwellings and windows for every room. Architects' reluctance to undertake daylight factor calculations, and the need to reduce window size to prevent solar gain, meet planning requirements and minimise construction costs, could explain why some surveyed schemes did not comply with daylight factor recommendations.

Address for correspondence: Alan Lewis, Manchester Architecture Research Centre (MARC), School of Environment and Development, University of Manchester, Humanities Bridgeford Street Building, Oxford Road, Manchester M13 9PL, UK E-mail: alan.lewis@manchester.ac.uk 


\section{Background}

Well-designed housing is recognised as having the potential to enhance older occupants' wellbeing and independence, ${ }^{1-4}$ thus preventing or delaying the need for care. ${ }^{5}$ In response to the UK's ageing population, recent years have seen considerable investment by both public and private sectors in specialist housing for older people, ${ }^{6}$ including in extra-care housing which provides occupants with selfcontained homes, and access to communal facilities and care support. ${ }^{7}$

Previous research has demonstrated the benefits of good daylighting in the homes of people with sight loss particularly in aiding detailed visual tasks. ${ }^{8}$ Daylight also has health benefits, particularly in helping the body to regulate the production of melatonin ${ }^{9-13}$, which in turn helps to regulate sleep patterns ${ }^{14-17}$, and in stimulating the body's production of serotonin, which can reduce the symptoms of depression. ${ }^{18-20}$

Eye pathologies, such as age-related macular degeneration, cataracts, glaucoma and diabetic retinopathy, are common amongst the older population. ${ }^{21,22}$ It would therefore seem reasonable to expect extra-care housing to be well designed for the needs of people with visual impairments, including with regard to daylighting. However, previous studies indicate that daylighting in older people's housing is sometimes poor, even where dwellings have been specifically designed for older people. ${ }^{23-25}$ This might reflect a lack of awareness of the 
lighting needs of older adults. ${ }^{25}$ More general studies of the uptake of daylighting guidance indicate that architects often rely on experience over calculation, which is an unsound approach. ${ }^{26,27}$ Recently some writers have speculated that the limitations of the daylight factor as a metric have contributed to architects' occasional disregard for daylighting. ${ }^{28-31}$

However, other possible explanations for building-designers' compliance or non-compliance with daylighting guidance should also be considered, not least because recent research demonstrates how construction projects are contingent on a wide range of social and economic forces. ${ }^{32,33}$ Better understanding of how these contingencies enable and constrain building designers will inform future daylighting guidance and practice. Relevant here is socio-technical theory, which has been applied to a range of fields including to the study of buildings' energy performance ${ }^{34}$, but which has had limited application to lighting. ${ }^{35,36}$ Following the socio-technical perspective, technical solutions alone will not lead to improved lighting standards, as building designers' actions are conditioned by an assemblage of social, economic and institutional factors. For example, window sizes are not determined by daylighting considerations alone, but by factors including construction costs, and designers' awareness of technical issues. Technical solutions are more likely to be successful when they are developed with an awareness of the ways in which contingencies enable and constrain the uptake of such solutions, and of where additional support or regulation might be required. 


\section{Aims and methodology}

This study aimed to identify barriers to compliance with current guidance on daylighting in the design of extra-care housing.

\subsection{Secondary analysis of EVOLVE data}

Secondary analysis was made of data collected for a previous study, entitled EVOLVE (Evaluation of Older People's Living Environments), which explored the relationship between building design and occupants' quality of life. ${ }^{1}$ EVOLVE included a survey, conducted March-December 2009, of 165 dwellings in 23 extra-care housing schemes in England, purposively sampled to ensure variety in building type and tenure (Table 1 ).

The EVOLVE survey tool featured numerous items on daylighting and was developed from design guidance including relevant British Standards, ${ }^{37}$ the SLL Code for Lighting, ${ }^{38}$ and those building standards required by some funding bodies and local planning authorities. ${ }^{39-45}$ Guidance on designing homes for people with sight loss was also incorporated, although this literature contains little on daylighting. ${ }^{46,47}$

During the survey, average daylight factors were calculated for the living room, kitchen and bedroom of each dwelling, using the formula developed by the Building Research Establishment (BRE) for light on a horizontal working plane at desktop height. ${ }^{37}$ The sky component was obtained using a dot diagram placed over a fisheye photograph, following a process described by Tregenza and Wilson. ${ }^{48}$ 
EVOLVE data were analysed for the current study using descriptive statistics, to explore the extent to which dwellings in the sample comply with current guidance on daylighting. The study's focus on individual dwellings reflects current guidance.

\subsection{Qualitative Interviews}

Semi-structured interviews were conducted with 20 people involved in the development and design of extra-care housing in the UK, including 14 architects, two representatives of not-for-profit housing providers, two commercial developers, and two code assessors (Table 2). The sample was purposive, with ten participants recruited because they designed housing schemes in the EVOLVE sample, and others recruited to ensure there was variety in terms of the building types on which participants had worked. In two cases interviews were conducted with two individuals who worked for the same company; in one case participants were interviewed separately (ENG1), while in the other (DEV1) the overall length of the interview was increased to ensure issues were covered in sufficient depth and, during data analysis, consideration was given to the participants' interaction dynamics. ${ }^{49}$ Interviewees were asked about briefing and the design process, with the aim of identifying barriers to compliance with daylighting guidance. Interviews lasted between 51 and 122 minutes, were recorded using a digital voice recorder and transcribed verbatim. Transcripts were anonymised to ensure confidentiality, and analysed using N-Vivo 9 software to store and retrieve data. An initial coding frame was 
developed based around themes identified through the review of design guidance. This coding frame permitted comparison between qualitative and quantitative data, enabling the qualitative data to be used to explore possible explanations for the findings of the quantitative study. Through the analysis process, themes were further refined to reflect the order in which building features, which affect daylighting, are normally considered in the design process, in accordance with the RIBA Plan of Work, ${ }^{50}$ starting with the overall building layout and progressing through to the design of individual elements such as windows and the installation of fittings. In analysing the data, efforts were made to identify any apparent agreement and contradiction between participants' responses.

\section{Findings}

The findings are presented in an order that reflects that in which building-design decisions affecting daylighting are typically made.

\subsection{Building layout: Sunlight and orientation}

The SLL Code for Lighting notes that dissatisfaction arises "as much from the permanent exclusion of sunlight as from its excess" and recommends that considerations of sunlight influence the building's form. ${ }^{38}$ The Housing Quality Indicators recommend that all kitchens and 
bathrooms have external windows, and that living room and kitchen windows are within $30^{\circ}$ of south or receive good daylight. ${ }^{41}$

The London Housing Design Guide notes that a dwelling with windows on at least two sides has "a greater chance of direct sunlight for longer periods" and recommends, "dual aspect should be the first option that designers explore for all new developments." ${ }^{44}$ Similarly, the report by Housing our Ageing Population: Panel for Innovation recommends the avoidance of internal corridors and single aspect apartments, in order to maximize natural light. ${ }^{45}$ The British Standards document BS-8206 Part 2: Code of Practice for Daylighting suggests that "providing additional illumination on the window wall from other windows" can also reduce glare from daylight. ${ }^{37}$

Secondary analysis of the EVOLVE study data shows that of the 165 dwellings surveyed, all living rooms and bedrooms had windows, while $45 \%$ (74 of 165) of kitchens, $8 \%$ (14 of 165) of bathrooms and 7\% (11 of 158) of hallways had natural light. This is partly explained by the fact that $63 \%$ (104 of 165) of dwellings in the sample were single aspect. It might also explain why, although $87 \%$ (144 of 165) of living rooms received direct sunlight during the morning or afternoon, only $28 \%$ (46 of 165) of living rooms received direct sunlight throughout the whole day (Table 3).

Interviewees identified several ways in which dual aspect dwellings could be achieved in the design of extra-care housing. Suggestions included the use of bungalows and cluster blocks (which generally have a greater external-surface-area-to-volume ratio than 
apartment blocks), deck access (where apartments are accessed via an open walkway), and additional windows in gable-end walls. It was also suggested that apartments could draw on borrowed daylight if they opened off atria or glazed single-bank corridors (where apartments line one side of the corridor only).

In describing the mechanisms by which older people's housing is funded and developed, a number of potential barriers to the construction of dual aspect dwellings were identified. Several interviewees talked about the need to maximize the number of dwellings on a site, driven partly by the increased revenue obtainable from each additional unit. Five architects and one developer (A2, A4, $A 12, A 13, A 14$ and DEV1a) suggested that an extra-care housing scheme requires at least 40 units for staffing and the provision of communal facilities to be financially viable. While one developer (DEV1a) suggested that a housing scheme with more than fifty units is difficult to manage, two other interviewees ( $\mathrm{A} 2$ and $\mathrm{A} 8$ ) claimed that housing providers and developers never look to reduce the number of dwellings on a site, with one architect observing:

"Everybody, without fail, wants as many units as possible, no-one ever tells us, "I only want forty units here." [They say,] "If I can get forty two I'll have that"...and the minute you draw forty three you can't ever go back, it's forty three or nothing... there's never any reduction, the figures get appraised, somebody punches it into a calculator, they tell their boss and off they go looking for the money and it doesn't stack up unless it 
meets those criteria. It only ever goes up, it never goes down" (Architect A2)

Another architect (A13) said that he would discuss with his clients the implications of, say, building 50 units rather than 40 , particularly if an additional storey would be needed which in turn might make it more difficult to obtain Local Authority planning consent. One architect (A14) felt that his clients usually have a good idea of how many units will fit on a site, and that architects are obliged to meet these expectations.

Several interviewees mentioned the need to consider a building's gross internal floor area, and two architects ( $A 6$ and A14) suggested that a housing scheme is viable only if around $65 \%$ of the floor area is given over to residential purposes and 35\% to communal facilities, services areas and circulation. One architect (A6) suggested that this ratio, which includes internal walls, is very difficult to achieve but necessary for sufficient revenue to be generated from the sale and letting of dwellings. Another architect (A14) explained that this ratio is generally not specified in the client's brief, but rather there is a general understanding that this allocation of space must be achieved. One consequence is the pressure to minimise the space given over to circulation (Architect A5).

One architect (A6) explained how contractors calculate construction costs on the basis of a building's floor area; the greater the floor area, the greater the anticipated construction cost. One architect 
(A1) believed that in the current economic climate, construction costs are critical.

Five architects and one housing provider (A1, A5, A6, A9, A11 and HP2) argued that the double banked corridor, where apartments open off both sides (Figure 1), is the most cost-effective type of circulation. By comparison, single banked corridors require routes that are twice as long, which impacts on the ratio of residential to communal floor-space, reduces the total number of dwellings that can be accommodated on a site, increases the length of service runs and increases the building's overall floor area hence raising construction costs. Two architects ( $\mathrm{A} 5$ and $\mathrm{A} 6$ ) noted that arranging the rooms in an apartment such that the kitchen has an external window similarly lengthens corridors (Figure 1).

The arguments against single banked corridors were also applied to the use of deck access and atria. In addition, one architect (A7) observed that apartments accessed via open decks or atria required cavity walls on both sides, unlike those that open off corridors that require only a single skin wall on the corridor side. Additional concerns about deck access included the anxiety that decks could become icy in winter, making them particularly unsuitable for older occupants. However, while one architect (A14) argued that deck access is unsuitable in the UK's climate, another (A2) cited precedents that show ice is not a problem with deck access. Architect A2 further suggested that decks should not be accessible from the street in order to avoid 
some of the security problems that have blighted deck access schemes in the past.
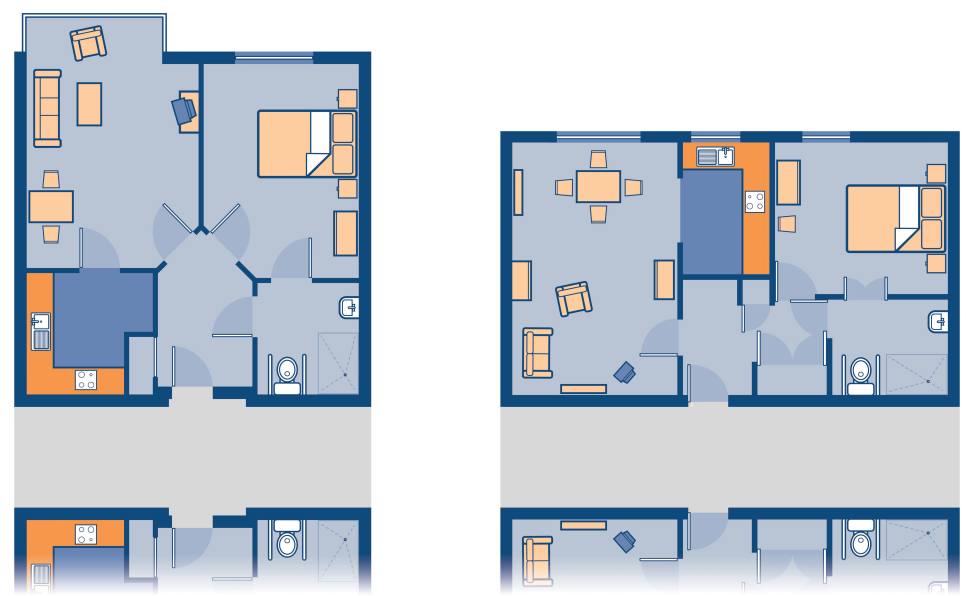

Figure 1. Apartments opening off a double-banked corridor. Where two apartments have an approximately equal floor area, the apartment that has an external-facing kitchen window (left) that will open off a longer corridor.

Some interviewees suggested that deck access is unfeasible in extra-care housing (A14) or possible only with "an unlimited budget" (HP2). Others had been involved in building deck access extra-care housing schemes (A2 and DEV1a), but admitted that it was more expensive than using double-banked corridors (DEV1a). For one developer (DEV1a), the principal attraction of deck access is that it 
allows kitchens to have windows, which he believed made it easier to sell apartments.

An architect, a housing provider and a developer (A7, HP2 and DEV1b) observed that in schemes where units are available for sale and property prices are high, the budget is usually a little more generous making feasible the inclusion of features such as atria. However, such features will be incorporated only if regarded as beneficial by the housing provider or developer, as ultimately financial returns are based on the number of units on a site (Architect A14). For example, a developer (A19) described how an atrium was included in a particular housing scheme because it was aimed at people who "have a bit more money" and "expect certain standard." Similarly a housing provider opted to develop a site with bungalows because they believed "that that was where the market was" even though the site could have been developed at a higher density using apartment blocks (A4).

\subsection{Building layout and window design: Aspect}

Although there is little guidance on aspect in relation to people with sight loss, previous research indicates that people with sight loss appreciate similar qualities in a view as people with normal vision. ${ }^{23}$ BS8206 and the Housing Quality Indicators recommend that buildings provide views of natural features or dynamic urban scenes. The latter adds the caveat that views should have a minimum depth of $50 \mathrm{~m}$, while BS-8206 emphasises the importance of depth for all views, suggesting that views should have distant, middle ground and foreground 
features. ${ }^{37,41}$ The Housing Quality Indicators and the Lifetime Homes standards suggest that windowsills should not be higher than $800 \mathrm{~mm}$ from finished floor level to allow a seated person to see out. ${ }^{41,43}$

Of the 165 dwellings in the EVOLVE sample, the view from the living room window included natural features in 79\% (130 of 165) of cases, human activity in $82 \%$ (135 of 165) of cases, and both near and far features in only $45 \%$ (74 of 165) of cases. Windowsills were less than $800 \mathrm{~mm}$ from floor level in 93\% (154 of 165) of the living rooms surveyed, while $78 \%$ (123 of 158) of bedrooms and no kitchens had low sills (Table 4).

Some interviewees suggested that the topography of some sites affords the creation of views over distance, particularly where a housing scheme is built on the side of a valley (A7, A10 and A14). Views over distance are harder to achieve on level ground and in built-up areas (A11 and DEV1a). One architect suggested that because many extracare dwellings are single aspect, apartments tend to face outwards to the street or inwards towards a garden or courtyard (A13). Both views, but particularly the former, will provide views of human activity, while the latter will usually provide views of natural features. Two architects noted the importance of not allowing dwellings to overlook neighbouring properties (A13 and A14), and several architects favoured organising dwellings around courtyards (A4, A5, A7, A8, A11 and A14). Several interviewees suggested that the recommended minimum sill height of $800 \mathrm{~mm}$ is too high to permit a seated person a good view (A1, A2, A4, A6, A7, A8, A14 and HP1). Achieving a lower sill is 
made complicated by the Building Regulation requirement that glass in windows, between the finished floor level and a height of $800 \mathrm{~mm}$, be robust or designed to break safely. ${ }^{51}$ Generally this requires the use of more expensive types of glass, which has an impact on construction costs (A9). It was suggested that construction costs could be minimised by putting a transom at $800 \mathrm{~mm}$, with toughened glass below and ordinary glass above (A8 and A9).

Other factors that make it difficult to create low sills include the need in some housing schemes to allow space for radiators under windows (A9, A14 and HP1) and to have service runs along external walls (A7), and the need to allow for furniture to be positioned under windows, often necessary where rooms are small (A9 and A14). Some interviewees suggested that for psychological reasons occupants might prefer low sills rather than floor to ceiling windows: One architect (A13) suggested that sills should be kept high in bedrooms to maintain occupants' privacy, while one architect and one housing provider (A1 and HP1) suggested that a higher sill offers a sense of security and prevents vertigo, although another architect (A2) disputed the idea that older people are more prone to vertigo.

\subsection{Window design: Daylight}

BS-8206 recommends that living rooms have a minimum average daylight factor of $1.5 \%$, kitchens $2 \%$ and bedrooms $1 \%{ }^{37}$ These recommendations are repeated in the SLL Code for Lighting ${ }^{38}$ and (with regard to living rooms and kitchens) BREEAM and the Code for 
Sustainable Homes. ${ }^{39,42}$ Recently, some writers have suggested that, in order for occupants to derive health benefits from daylight, at least one habitable room should have a minimum average daylight factor of $2 \% .{ }^{48}$

BS-8206 advises that daylight should be uniformly distributed within a room and suggests that this will be satisfied if $80 \%$ of the working plane lies within the no-sky line and that single aspect rooms are not too deep in comparison with the height and width of the windows, in accordance with a formula provided. ${ }^{37}$ These recommendations are repeated in $\mathrm{BREEAM}^{39}$ and, with regard to the no-sky line, the Code for Sustainable Homes. ${ }^{42}$

Of the 165 dwellings in the EVOLVE sample, 45\% (74 of 165) of living rooms, no kitchens and 44\% (69 of 158) of bedrooms complied with recommendations on minimum average daylight factor of $1.5 \%, 2 \%$ and $1 \%$ respectively (Table 5 ). Of the 23 housing schemes evaluated, $48 \%$ (11 of 23 ) had a median average daylight factor in living rooms above $1.5 \%$, while $55 \%$ (12 of 22 ) had a median average daylight factor in bedrooms above 1\% (Table 6). Dwellings with higher average daylight factors had larger windows and fewer external obstructions; while some dwellings on higher floors had fewer obstructions than those on lower storeys, the presence of overhanging eaves or balconies obstructed some windows (Figure 2). Reflectance was similar in most dwellings, with 93\% (154 of 165) of living rooms, 96\% (71 of 74) of kitchens and 94\% (149 of 158) of double bedrooms being decorated in a light colour (Table 5). 
Using the formula published in BS-8206 for single aspect rooms, $73 \%$ (100 of 137) of living rooms, $98 \%$ (58 of 59) of kitchens and 97\% (148 of 153) of bedrooms have a depth that is not too large in comparison with the window height (Table 5).

Barriers to compliance with guidance on the quantity and distribution of daylight, identified through interviews, can be divided into two categories: those relating to daylight prediction methods (further divided here into manual and digital methods), and other determinants of window size.
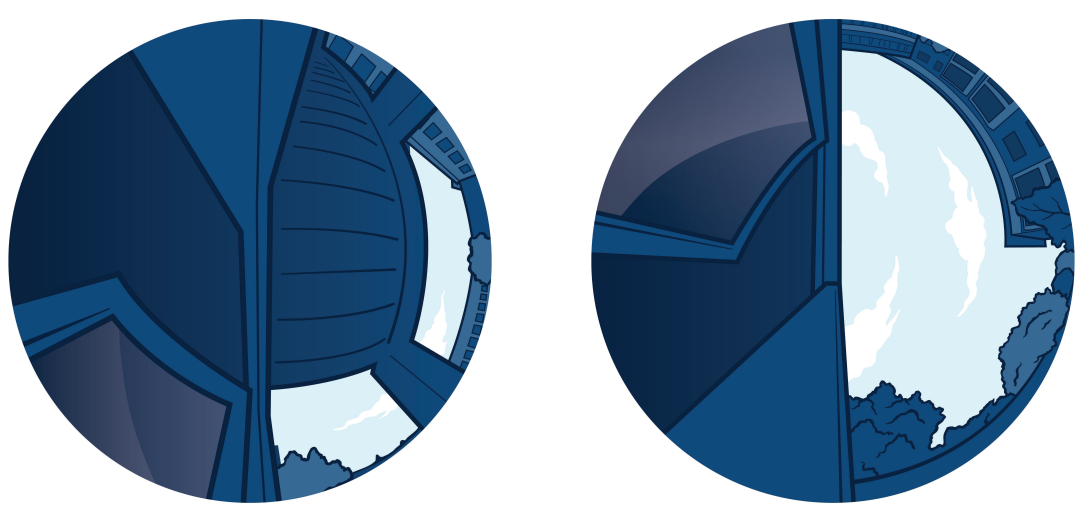

Figure 2. For daylight factor calculations, the visible sky component was measured using a dot diagram overlaid on a fisheye photograph. These drawings, made from two of the fisheye photographs, provide an example of an instance where the sky component was low due to the presence of a balcony over a window (left), and an instance where the sky component was relatively high (right). 


\subsubsection{Daylight prediction: Manual methods}

Of the 14 architects interviewed for this study, four admitted that they had never undertaken any daylight factor calculations (A10, A11, A12 and A14). Two architects did not remember learning about daylight factors at university (A10 and A14), while three remembered that daylight factors were covered as part of a lecture course but there was no expectation that they should be used in the design studio (A11, A12 and A13). One architect suggested that engineers are more suited to undertaking calculations than architects (A11).

Seven architects described how, when designing a building, they rely primarily on their experience to judge whether a room is likely to have sufficient daylight ( $A 1, A 3, A 4, A 5, A 6, A 11$ and $A 14)$. Two explained how they privilege experience over calculation ( $A 3$ and $A 4)$. Two other architects pointed out that most apartments are similar (A5 and A12). Some architects had used daylight factor calculations when designing buildings in the past, but felt that changes to fee structure had made it uneconomical to do so as building designs are now "more formulaic" (A8) and spending time on calculations "eats into the profit margin" (A10).

Where it is necessary to provide evidence that a building complies with recommended minimum daylight factors, in order to obtain credits under the Code for Sustainable Homes or BREEAM, many of the architects interviewed expected this work to be undertaken by other consultants, such as code assessors (A4, A5, A6, A9 and A11), mechanical and electrical engineers (A7, A8 or DEV1a) or in-house 
environmental specialists (A2). In some instances code assessors advised architects against trying to obtain the daylighting credits available under these codes on the grounds that it was too difficult (A12 and A14), although some architects ignored this advice (A12).

One architect (A9) suggested that code assessors are not always thorough in calculating daylight factors, disregarding the impact of features such as overhanging eaves. A code assessor (ENG12b) suggested that when the Code for Sustainable Homes was introduced it was considered acceptable to use a default angle of $65^{\circ}$ for the vertical sky component (Figure 3), but more recently the organisations that accredit code assessors had tightened up on working practices such that now assessors are expected to measure the sky component more accurately, making site visits if necessary. Accreditation companies enforce this by assessing a sample of an assessor's work. However, assumptions are still made about the height of existing neighbouring buildings based on code assessors' knowledge of typical storey-height.

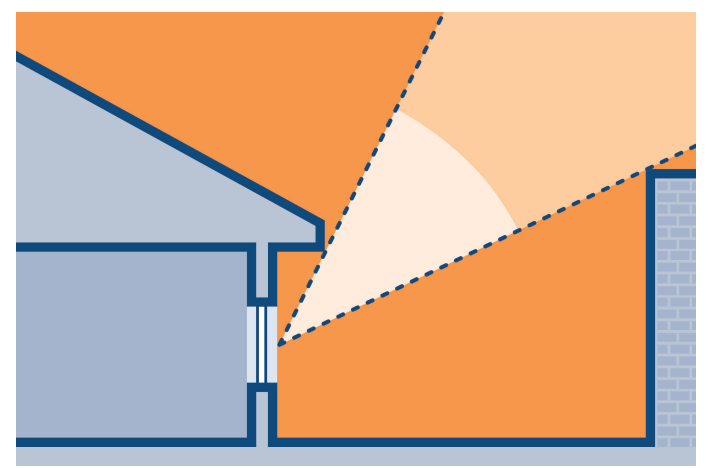

Figure 3. One interviewee reported using a default angle of $65^{\circ}$ for the vertical sky component, when assessing daylight factors at the design stage. 


\subsubsection{Daylight prediction: Digital methods}

Three architects reported that they use BIM (Building Information Modelling) (A2, A9 and A12) and some interviewees suggested that such software might allow detailed assessment of daylight levels at the design stage (A1, A8, A10 and A11). However, other interviewees pointed out that it takes a long time to input data into a BIM model, such that a scheme must be largely resolved before it can be tested ( $A 2, A 4$ and $A 12)$, and one architect suggested that a building design must still begin with a "back of the envelope" calculation (A11). Some architects were unconvinced that the necessary investment of time and money would lead to increased returns (A5, A6, A7 and A13), and it was pointed out that architect's clients are generally unwilling to pay for the technical development of a scheme until planning consent has been secured, by which time most of the design decisions affecting daylighting have been made (A11).

\subsubsection{Other factors that determine window size}

Other than considerations of daylighting, factors that affect the size of windows include the need for new buildings to comply with energy performance criteria. These include those criteria set out in the Building Regulations ${ }^{52}$ and, where required by local planning authorities and public funding bodies, those in the Code for Sustainable Homes or BREEAM.

One architect (A8) suggested that the need to comply with energy performance criteria takes precedence over considerations of daylighting in the design of windows. Several architects (A6, A8, A9 and 
A14) described how they start by designing windows based on experience and personal judgement, before testing the impact of the windows on the building's energy performance through calculations. As with daylight factor calculations, consultants other than architects often undertake the evaluation of a building's predicted energy performance (A8 and A14).

While four interviewees (A7, A8, A12 and HP1) felt that larger windows would lead to greater heat loss from the building, another four ( $A 2, A 4, A 9$ and $A 14)$ suggested that the thermal performance of new windows is now so good that heat loss through windows is no longer a major concern. Some interviewees (A6, A14 and HP1) claimed that if calculations demonstrate that a building is likely to lose excessive heat, they prefer to compensate by adding insulation to the walls and roof rather than reducing the size of windows, so as to avoid reducing the amount of daylight in the building. In practice, only two architects (A7 and A8) had, in response to the results of energy calculations, reduced window sizes at the design stage in order to limit heat loss. Six interviewees ( $A 1, A 2, A 4, A 6, A 9$ and $H P 2)$ suggested that excessive solar gain is an increasing concern, as buildings become better insulated in order to satisfy increasingly strict energy performance criteria. Four architects (A2, A4, A8 and A9) had, at the design stage, reduced window sizes due to concerns about solar gain.

Some architects felt that planning considerations can affect window size and shape. Architects anticipate what style will be acceptable to a local planning authority, and some architects (A1, A4, 
A6, A12 and A14) believed that windows needed to be smaller when designing in areas with historic buildings. One architect's experience of designing a housing scheme for a Conservation Area was that the window's size was unaffected, but that windows needed a shape that matched those of the surrounding Victorian buildings (A3).

Several architects suggested that glazing is more expensive than masonry, when calculated by area (A1, $A 2, A 6$ and $A 12)$. This is partly due to the need for associated structural elements, such as lintels (A2, A6 and A9). One architect (A6) suggested that corner windows are particularly expensive because of the steelwork required. Curtain wall glazing, which is sometimes used in communal areas, is also expensive and often requires an additional supplier to be brought into the supply chain. Also, as curtain wall glazing can be difficult to maintain, it is sometimes necessary to specify self-cleaning glass, which is more expensive that ordinary glass. Therefore, contractors often prefer to use regular glazing with standard components that can be "bought off the shelf' (A9).

Building contractors will sometimes ask for smaller windows in order to reduce construction costs ( $A 1, A 2$ and $A 13)$, although one architect (A1) suggested that there is usually little pressure to do this provided the design is "fairly sensible" and particularly if planning consent has been received, as any design changes affecting the building's appearance would necessitate the resubmission of the planning application. Another architect provided an example of a project where a contractor, immediately prior to the submission of the 
full planning application, asked for all the windows in a housing scheme to be reduced in size as part of his final cost review: "... The contractor phoned up... and said oh we're half a million pounds over, will you make all the windows smaller? And we said no... first of all there's a logistical problem, we've got to change every single drawing... there's a design issue because the architecture will change... we don't just make this stuff up... things have got to be in proportion and most importantly, the client [is] expecting this amount of glazing..." (A2) The architect agreed to remove a proposed glazed link in order to balance the budget, rather than reduce the window sizes, noting that: "This happens all the time, you know, and even if [the windows are] not too expensive someone looks to lower their budget and make changes and they always... look at the amount of glazing" (A2)

Window sizes are further constrained by the need to consider what an occupant can reach in cleaning reversible windows (A5 and A9). One architect (A9) observed that maintenance staff can clean windows in communal areas, and consequently these windows can be larger than those in apartments or bungalows. Another architect (A1) noted that the size of opening lights is limited by the weight of glass that the hinges will hold.

Interviewees suggested that window head height is normally $2.1 \mathrm{~m}$ above finished floor level, in line with the height of internal doors $(A 1, A 4, A 5, A 7, A 8, A 11$ and $A 14)$. This also allows window heads to align with brick and block courses, minimising construction costs, as bricks do not have to be cut (A7). Space is required above the window 
for curtains and blinds (A5, A7, A14 and HP1). Ceilings are $2.4 \mathrm{~m}$ above floor level by convention and contractors are often reluctant to build ceilings higher because of the associated additional construction costs; this in turn restricts window head height (A1). External appearance is also a consideration and sometimes a lower window head is used if a "cottage style" building is required (A8).

\subsection{Solar shading: Prevention of glare}

Guidance on designing for people with sight loss highlights the

need for blinds to enable occupants to minimise glare from sunlight. ${ }^{46,47}$ Building Sight also notes that some occupants find blinds difficult to adjust, and recommends that consideration be given to structural shading. The SLL Code for Lighting observes that fixed shading (including brise soleil, balconies and eaves) generally reduces the skylight admitted, while internal shades are often ineffective in reducing solar gain, although they can prevent glare. It is suggested that solar control is best achieved "by careful planning of the orientation and disposition of rooms and their windows" ${ }^{38}$

The EVOLVE survey recorded that $51 \%$ (77 of 151) of living rooms in the sample, $64 \%$ (35 of 55) of kitchens and $55 \%$ (74 of 134) of bedrooms, had internal Venetian or vertical blinds. Of these solar shades, 95\% (73 of 77) in living rooms, 100\% (35 of 35) in kitchens and $100 \%$ (74 of 74) in bedrooms fully covered the window (Table 7). Interviewees reported that occupants are generally expected to fit their own blinds (A6, A14, HP2 and DEV1a), but in some instances 
blinds are installed as part of the construction project, such as where a scheme is designed specifically for people with sight loss (A6) or where there are concerns about a building's appearance (A11). Brise soleil were used in some housing schemes, primarily for communal facilities (A10, A11 and HP1), but some architects found the cost prohibitive (A6). Some interviewees reported that they used balconies as solar shading (A7, A10 and HP1).

\section{Conclusion}

While all 165 dwellings surveyed had windows to living rooms and bedrooms, only $45 \%$ (74 of 165) of kitchens and $8 \%$ (14 of 165) of bathrooms had natural light. Similarly, while $87 \%$ (144 of 165) of living rooms received some sunlight, only $28 \%$ (46 of 165) received sunlight throughout the day. The number of deep-plan, single aspect dwellings in the sample can explain both these findings; $63 \%$ (104 of 165) of the dwellings were single aspect. Interviewees identified drivers for the use of this typology, including the need to maximise the number of units on the site in order to obtain the highest possible financial returns, and the need to minimise the total floor area in order to keep construction costs down, which in turn leads to pressure to minimise the floor area used for circulation. Bungalows, atria and deck access, which often require sites to be developed at lower densities and with larger circulation areas, are generally used only where the sales value of homes is high and where developers or housing providers believe these features will 
attract more customers. This raises questions about the feasibility of complying with recommendations regarding dual aspect dwellings in the design of extra-care housing. ${ }^{45}$

Of the dwellings surveyed, $45 \%$ (74 of 165 ) of living rooms, $44 \%$ (69 of 158) of bedrooms and no kitchens complied with recommendations on minimum average daylight factor of $1.5 \%, 1 \%$ and $2 \%$, respectively. Daylight factors are affected by window size, and there seemed to be few constraints on incorporating large windows into extra-care housing schemes. While concerns about solar gain sometimes constrained window size, interviewees suggested that they had fewer concerns about potential heat loss through windows owing to the improved thermal performance of modern windows and the possibility that thermal insulation could be added elsewhere to compensate. Planning restrictions reportedly constrained window size in some historic areas. Concerns to minimise construction costs by reducing glazing could often be addressed by using conventional components rather than curtain wall glazing. Echoing previous research, ${ }^{26-28}$ most architects interviewed for this study rarely undertook daylight factor calculations and this possibly caused them to lack awareness of how their housing schemes measured up to current standards, which would explain the survey findings. This problem seems to be compounded by the reluctance of architects' clients to pay for housing schemes' technical development until planning consent is secured, by which time most of the key design decisions have been made. Possible solutions to these problems include better education for 
architects, compulsory daylighting standards, and simple tools such as improved metrics and software.

\section{Funding}

This study was funded by the Thomas Pocklington Trust under grant \#B10682. The EVOLVE study was funded by the EPSRC (Engineering and Physical Sciences Research Council) under grant \#EP/F000774/1.

\section{Acknowledgements}

The author would like to thank Dr Lynn Watson of Thomas Pocklington Trust, Peter Tregenza, Emeritus Professor of the University of Sheffield, and Judith Torrington, formerly of the University of Sheffield, for their assistance with this research.

\section{References}

1. Orrell A, McKee K, Torrington J, Barnes S, Darton R, Netten A, Lewis A. The relationship between building design and residents' quality of life in extra care housing schemes. Health and Place 2013; 21: 52-64. 
2. Parker C, Barnes S, McKee K, Morgan K, Torrington J, Tregenza P. Quality of life and building design in residential and nursing homes for older people. Ageing and Society 2004; 24: 941-962.

3. Evans G, Kantrowitz E, Eshelman P. Housing quality and psychological well-being among the elderly population. The Journals of Gerontology: Series B, Psychological Sciences and Social Sciences 2002; 57: 381-383. 4. Wahl H-W, Schilling O, Oswald F, Iwarsson, S. The home environment and quality of life-related outcomes in advanced old age: findings of the ENABLEAGE project. European Journal of Ageing 2009; 6: 101-111.

5. Department of Communities and Local Government. Laying the Foundations: A Housing Strategy for England. London: Communities and Local Government Publications, 2011.

6. Darton R, Callaghan L. The role of extra care housing in supporting people with dementia: early findings from the PSSRU evaluation of ECH. Journal of Care Services Management 2009; 3: 284-294.

7. Riseborough M, Fletcher, P. Extra Care Housing: What is it? Factsheet A1. London: Housing LIN, 2004.

8. Littlefair P. Research Findings No.30: Daylighting and windows in homes of people with sight loss. London: Thomas Pocklington Trust, March 2010.

9. Lewy AJ, Wehr TA, Goodwin FK, Newsome DA, Markey SP. Light suppresses melatonin secretion in humans. Science 1980; 210: 12671269. 
10. McIntyre IM, Norman TR, Burrows GD, Armstrong S. Human melatonin suppression is intensity dependent. Journal of Pineal Research 1989; 6: 149-156.

11. Brainard GC, Rollag MD, Hanifin JP. Photic regulation of melatonin in humans: ocular and neural signal transduction. Journal of Biological Rhythms 1997; 12: 537-546.

12. Brainard GC, Hanifin JP, Greeson JM, Byrne B, Glickman G, Gerner E, Rollag MD. Action spectrum for melatonin regulation in humans: evidence for a novel circadian photoreceptor. Journal of Neuroscience 2001; 21: 6405-6412.

13. Thapan K, Arendt J, Skene DJ. An action spectrum for melatonin suppression: evidence for a novel non-rod, non-cone photoreceptor system in humans. Journal of Physiology 2001; 535: 261-267. 14. Wehr T, Aeschbach D, Duncan WJ. Evidence for a biological dawn and dusk in the human circadian timing system. The Journal of Physiology 2001; 535: 937-951.

15. Lockley SW, Dijk DJ. Functional genomics of sleep and circadian rhythm. Journal of Applied Physiology 2002; 92: 852-862.

16. Wright $\mathrm{H}$, Lack L. Effect of light wavelength on suppression and phase delay of the melatonin rhythm. Chronobiology International 2001; 18: 801-808.

17. Van Someren E, Kessler A, Mirmirann M, Swaab D. Indirect bright light improves circadian rest-activity rhythm disturbances in demented patients. Biological Psychiatry 1997; 41: 955-963. 
18. Rosenthal NE. Winter Blues: Seasonal Affective Disorder, What It Is and How to Overcome It. New York: Guildford Press, 1993.

19. Rosenthal NE, Sack DA, Gillin C, Lewy AJ, Goodwin FK, Davenport Y, Mueller PS, Newsome DA, Wehr TA. Seasonal Affective Disorder - A description and preliminary findings with white light therapy. Archives of General Psychiatry 1984; 41: 72-80.

20. Lewy AJ, Nurnberger JI, Wehr TA, Pack D, Becker LE, Powell RL, Newsome DA. Supersensitivity to light: possible trait marker for manic depressive illness. American Journal of Psychiatry 1985; 142: 725-727. 21. Adult Social Care Statistics, Health and Social Care Information Centre. Registered Blind and Partially Sighted People - Year Ending 31 March 2014. London: Health and Social Care Information Centre, 2014. 22. Bunce C, Wormald R. Leading causes for certification for blindness and partial sight in England and Wales. BMC Public Health 2006; 6: 58. 23. Lewis A, Torrington J. Extra-care housing for people with sight loss: Lighting and design. Lighting Research and Technology 2013; 45: 345361.

24. Bakker R, Lofel $Y$, Lachs $M$. Lighting levels in the dwellings of homebound older adults. Journal of Housing for the Elderly 2004; 18 : 17-27.

25. Sinoo M, van Hoof J, Kort HSM. Light conditions for older adults in the nursing home: Assessment of environmental illuminances and colour temperature. Building and Environment 2011; 46: 1917-1927. 26. Croghan D, Hawkes D. Daylighting in dwellings: 3 - Analysis of a questionnaire. The Architects' Journal 1969: 585-589. 
27. Aizlewood M, Littlefair P. Daylight Prediction Methods: A Survey of their Use. Garston: Building Research Establishment, 1994.

28. Reinhart C. Effects of interior design on the daylight availability in open plan offices. In: Proceedings of the ACEEE Summer Study on Energy Efficient Buildings. Pacific Grove, CA, August 2002.

29. Mardaljevic J. Examples of climate-based daylight modeling. In: Proceedings of CIBSE National Conference 2006: Engineering the Future. London, UK, 21-22 March 2006.

30. Cantin F, Dubois M-C. Daylighting metrics based on illuminance, distribution, glare and directivity. Lighting Research and Technology 2011; 43: 291-307.

31. Leslie RP, Radetsky LC, Smith AM. Conceptual design metrics for daylighting. Lighting Research and Technology 2012; 44: 277-290.

32. Till J. Architecture Depends. Cambridge, MA: MIT Press, 2009.

33. Awan N, Schneider T, Till J. Spatial Agency: Other Ways of Doing Architecture. London: Routledge, 2011.

34. Guy S, Shove E. A Sociology of Energy, Buildings and the Environment. London: Routledge, 2000.

35. Bijker WE. Of Bicycles, Bakelites, and Bulbs: Toward a Theory of Sociotechnical Change. Cambridge, MA: MIT Press, 1995.

36. Bijker WE. The social construction of fluorescent lighting, or how an artifact was invented in its diffusion stage. In: WE Bijker and J Law (eds) Shaping Technology/Building Society: Studies in Sociotechnical Change. Cambridge, MA: MIT Press, 1992, pp.75-102. 
37. British Standards Institution. BS-8206-2: 2008 Lighting for Buildings - Part 2: Code of Practice for Daylighting. London: BSI, 2008.

38. The Society of Light and Lighting. SLL Code for Lighting. London: CIBSE, 2012.

39. BREEAM. Scheme Document SD 5064: BREEAM Multi-Residential 2008. Watford, UK: BRE Global, 2012.

40. Housing Corporation. Design and Quality Standards. London: Housing Corporation, 2007.

41. The National Affordable Homes Agency. 721 Housing Quality Indicators (HQI) Form. London: Housing Corporation, 2008.

42. Department for Communities and Local Government. Code for Sustainable Homes: Technical Guide. London: Communities and Local Government Publications, 2010.

43. Lifetime Homes, 16 Design Criteria from 5 July 2010, Last accessed April 2011 from http://www.lifetimehomes.org.uk/index.php. 44. Mayor of London. London Housing Design Guide - Interim Edition. London: London Development Agency, 2010.

45. Housing our Ageing Population: Panel for Innovation (HAPPI). London: Homes and Communities Agency, 2009.

46. Goodman C. Housing for People with Sight Loss: A Thomas Pocklington Trust Design Guide. London: Thomas Pocklington Trust, 2008.

47. Barker P, Barrick J, Wilson R. Building Sight: Handbook of Building and Interior Design Solutions to Include the Needs of Visually Impaired People. London: RNIB, 1995. 
48. Tregenza P, Wilson M. Daylighting - Architecture and Lighting Design. London: Routledge, 2011.

49. DiCicco-Bloom B, Crabtree BF. The qualitative research interview. Medical Education 2006; 40: 314-321.

50. Royal Institute of British Architects. RIBA Plan of Work 2013. London: RIBA, 2013.

51. HM Government. The Building Regulations 2010: Approved Document N. London: NBS (part of RIBA Enterprises Ltd.), 2010. 52. HM Government. The Building Regulations 2010: Approved Document L1A. London: NBS (part of RIBA Enterprises Ltd.), 2010. 
Table 1 Building types included in EVOLVE quality of life study

\begin{tabular}{|c|c|c|c|c|c|}
\hline $\begin{array}{l}\text { Housing } \\
\text { Scheme }\end{array}$ & $\begin{array}{l}\text { Not-for- } \\
\text { Profit/Private }\end{array}$ & $\begin{array}{l}\text { No. of } \\
\text { Units }\end{array}$ & Storeys* & $\begin{array}{l}\text { Year Constructed } \\
\text { (Remodelled) }\end{array}$ & Building Type \\
\hline 1 & Not-for-Profit & 42 & 3 & 2004 & Small apartment block \\
\hline 2 & Private & 78 & 3 & 2008 & Large apartment block \\
\hline 3 & Not-for-Profit & 37 & 3 & 2008 & $\begin{array}{l}\text { Small apartment block; } \\
\text { bungalows }\end{array}$ \\
\hline 4 & Not-for-Profit & 40 & 4 & 2008 & Small apartment block \\
\hline 5 & Private & 225 & 3 & 2006 & Cluster blocks \\
\hline 6 & Not-for-Profit & 40 & 11 & 1960s (r2006) & Tower block \\
\hline 7 & Not-for-Profit & 46 & 4 & 2007 & Small apartment block \\
\hline 8 & Not-for-Profit & 46 & 4 & 2007 & Small apartment block \\
\hline 9 & Not-for-Profit & 38 & 4 & 2006 & Small apartment block \\
\hline 10 & Not-for-Profit & 50 & 3 & 2006 & $\begin{array}{l}\text { Small apartment block in } \\
\text { village }\end{array}$ \\
\hline 11 & Not-for-Profit & 50 & 2 & 2006 & Small apartment block \\
\hline 12 & Not-for-Profit & 40 & 3 & 2007 & Small apartment block \\
\hline 13 & Not-for-Profit & 63 & 4 & 2008 & Small apartment block \\
\hline 14 & Not-for-Profit & 59 & 3 & 1986 (r2006) & Small apartment block \\
\hline 15 & Not-for-Profit & 39 & 3 & 2002 & Small apartment block \\
\hline 16 & Not-for-Profit & 50 & 2 & 2004 & Small apartment block \\
\hline 17 & Private & 152 & 2 & 1999 & $\begin{array}{l}\text { Bungalows (some with } \\
\text { rooms in roof space); } \\
\text { central facilities block }\end{array}$ \\
\hline 18 & Not-for-Profit & 37 & 3 & 1995 (r2005) & Small apartment block \\
\hline 19 & Not-for-Profit & 217 & 5 & 2008 & $\begin{array}{l}\text { Large apartment block; } \\
\text { bungalows }\end{array}$ \\
\hline 20 & Not-for-Profit & 39 & 2 & 1975 (r2004) & Small apartment block \\
\hline 21 & Not-for-Profit & 30 & 2 & 1978 (r2005) & Small apartment block \\
\hline 22 & Not-for-Profit & 242 & 4 & 2008 & $\begin{array}{l}\text { Large apartment block } \\
\text { with atrium and corridor } \\
\text { access; cluster blocks; 2- } \\
\text { storey houses }\end{array}$ \\
\hline 23 & Not-for-Profit & 64 & 3 & 2007 & Small apartment block \\
\hline
\end{tabular}

* All individual dwellings, except for a small number in schemes 17 and 22, were single storey. 
Table 2 Interviewees

\begin{tabular}{|c|c|c|c|c|c|}
\hline Interviewee & Business/Profession & Position & $\begin{array}{l}\text { Number of } \\
\text { full time staff }\end{array}$ & $\begin{array}{l}\text { In-house } \\
\text { engineers? }\end{array}$ & $\begin{array}{l}\text { In-house } \\
\text { code } \\
\text { assessors? }\end{array}$ \\
\hline A1 & Architect & Director & 9 & No & No \\
\hline A2 & Architect & Partner & 470 & Yes & Yes \\
\hline A3 & Architect & Partner & 5 & No & No \\
\hline A4 & Architect & Partner & 4 & No & No \\
\hline A5 & Architect & Associate Director & 9 & No & No \\
\hline A6 & Architect & Senior Technician & 7 & No & Yes \\
\hline A7 & Architect & Director & 5 & No & No \\
\hline A8 & Architect & Director & 98 & No & Yes \\
\hline A9 & Architect & Director & 15 & No & No \\
\hline A10 & Architect & Project Architect & 26 & No & No \\
\hline A11 & Architect & Associate & 17 & No & Yes \\
\hline A12 & Architect & Associate & 98 & No & Yes \\
\hline A13 & Architect & Director & 12 & No & No \\
\hline A14 & Architect & $\begin{array}{l}\text { Architectural } \\
\text { Technologist }\end{array}$ & 12 & No & No \\
\hline ENG1a* & $\begin{array}{l}\text { Mechanical and } \\
\text { Electrical Engineers }\end{array}$ & Director & & & \\
\hline ENG1b* & $\begin{array}{l}\text { Mechanical and } \\
\text { Electrical Engineers }\end{array}$ & $\begin{array}{l}\text { "Carbon } \\
\text { Consultant" }\end{array}$ & & & \\
\hline HP1 & $\begin{array}{l}\text { Not-for-profit } \\
\text { Housing Provider }\end{array}$ & $\begin{array}{l}\text { Development } \\
\text { Manager }\end{array}$ & & & \\
\hline HP2 & $\begin{array}{l}\text { Not-for-profit } \\
\text { Housing Provider }\end{array}$ & Head of Estates & & & \\
\hline DEV1a** & $\begin{array}{l}\text { Private Housing } \\
\text { Developer }\end{array}$ & Company Chairman & & & \\
\hline DEV1b** & $\begin{array}{l}\text { Private Housing } \\
\text { Developer }\end{array}$ & Design Manager & & & \\
\hline
\end{tabular}

* These two interviewees worked for the same company.

** These two interviewees worked for the same company. 
Table 3 Building layout: Sunlight and orientation

\begin{tabular}{|c|c|c|c|c|}
\hline & & $\begin{array}{l}\text { Number of rooms } \\
\text { to which item } \\
\text { applicable }\end{array}$ & $\begin{array}{l}\text { Number of rooms } \\
\text { that comply }\end{array}$ & $\begin{array}{l}\text { Percentage of rooms } \\
\text { that comply (\%) }\end{array}$ \\
\hline \multirow{6}{*}{$\begin{array}{l}\text { The room has } \\
\text { natural light } \\
\text { n1*, } 46^{* *}\end{array}$} & hall & 158 & 11 & 7 \\
\hline & living room & 165 & 165 & 100 \\
\hline & kitchen & 165 & 74 & 45 \\
\hline & $\mathrm{d}$ bed & 158 & 158 & 100 \\
\hline & s bed & 61 & 61 & 100 \\
\hline & bath & 165 & 14 & 8 \\
\hline $\begin{array}{l}\text { The dwelling is dual } \\
\text { aspect }^{41,44,45}\end{array}$ & $\begin{array}{l}\text { (whole } \\
\text { dwelling) }\end{array}$ & 165 & 61 & 37 \\
\hline \multirow{4}{*}{$\begin{array}{l}\text { The room receives } \\
\text { sunlight in the } \\
\text { morning or in the } \\
\text { afternoon } 44\end{array}$} & living room & 165 & 144 & 87 \\
\hline & kitchen & 74 & 55 & 74 \\
\hline & $d$ bed & 158 & 134 & 85 \\
\hline & s bed & 61 & 52 & 85 \\
\hline \multirow{4}{*}{$\begin{array}{l}\text { The room receives } \\
\text { sunlight in the } \\
\text { morning and in the } \\
\text { afternoon }{ }^{41^{* * *}}\end{array}$} & living room & 165 & 46 & 28 \\
\hline & kitchen & 74 & 12 & 16 \\
\hline & $\mathrm{d}$ bed & 158 & 40 & 25 \\
\hline & $\mathrm{s}$ bed & 61 & 18 & 30 \\
\hline \multirow{3}{*}{$\begin{array}{l}S, E, W \text { facing } \\
\text { windows are free } \\
\text { from obstruction to } \\
\text { direct sunlight }{ }^{41^{* * * *}}\end{array}$} & living room & 151 & 77 & 51 \\
\hline & kitchen & 55 & 35 & 64 \\
\hline & $\mathrm{d}$ bed & 134 & 72 & 54 \\
\hline
\end{tabular}

* Recommends that kitchens and bathrooms have windows.

** Suggests that natural light "should be maximised in task areas" such as at the kitchen sink, and on circulation routes.

*** Recommends that the living room/kitchen window be "within 30 degrees of South or gets good daylight"

**** Recommends "Principal rooms have windows that do not look out on wall within

$3 m^{\prime \prime}$ 
Table 4 Building layout and window design: Aspect

\begin{tabular}{|c|c|c|c|c|}
\hline & & $\begin{array}{l}\text { Number of rooms } \\
\text { to which item } \\
\text { applicable }\end{array}$ & $\begin{array}{l}\text { Number of rooms } \\
\text { that comply }\end{array}$ & $\begin{array}{l}\text { Percentage of rooms } \\
\text { that comply (\%) }\end{array}$ \\
\hline \multirow{4}{*}{$\begin{array}{l}\text { The view from the } \\
\text { window consists } \\
\text { of natural features } \\
37,41^{*}\end{array}$} & living room & 165 & 130 & 79 \\
\hline & kitchen & 74 & 62 & 84 \\
\hline & $\mathrm{d}$ bed & 158 & 119 & 75 \\
\hline & $s$ bed & 61 & 39 & 64 \\
\hline \multirow{4}{*}{$\begin{array}{l}\text { The window(s) } \\
\text { overlook outdoor } \\
\text { spaces where } \\
\text { there is human } \\
\text { activity } \\
37^{* *}\end{array}$} & living room & 165 & 135 & 82 \\
\hline & kitchen & 74 & 51 & 69 \\
\hline & $\mathrm{d}$ bed & 158 & 112 & 71 \\
\hline & s bed & 61 & 42 & 69 \\
\hline \multirow{4}{*}{$\begin{array}{l}\text { The view from the } \\
\text { window consists } \\
\text { of near and } \\
\text { distant features of } \\
\text { interest } 37,41^{*}\end{array}$} & living room & 165 & 74 & 45 \\
\hline & kitchen & 74 & 29 & 39 \\
\hline & $\mathrm{d}$ bed & 158 & 61 & 39 \\
\hline & $\mathrm{s}$ bed & 61 & 26 & 43 \\
\hline \multirow{4}{*}{$\begin{array}{l}\text { The view from the } \\
\text { window is free } \\
\text { from obstructions, } \\
\text { e.g. a blank wall } \\
41^{* * *}\end{array}$} & living room & 165 & 127 & 77 \\
\hline & kitchen & 74 & 59 & 80 \\
\hline & $\mathrm{d}$ bed & 158 & 114 & 72 \\
\hline & s bed & 61 & 50 & 82 \\
\hline \multirow{3}{*}{$\begin{array}{l}\text { The sill height is } \\
\text { less than } 800 \mathrm{~mm} \\
\text { above floor level } \\
37,41,43\end{array}$} & living room & 165 & 154 & 93 \\
\hline & kitchen & 74 & 0 & 0 \\
\hline & $\mathrm{d}$ bed & 158 & 123 & 78 \\
\hline
\end{tabular}

* Recommends that "At least one main living area has urban views of over 50m OR distant or rural views"

** Suggests: "When only buildings, sky and street can be seen, it is especially desirable that the view be dynamic, i.e. including the activities of people outside and the changing weather"

*** Recommends "Principal rooms have windows that do not look out on wall within $3 m^{\prime \prime}$ 
Table 5 Window design: Daylight

\begin{tabular}{|c|c|c|c|c|}
\hline & & $\begin{array}{l}\text { Number of rooms } \\
\text { to which item } \\
\text { applicable }\end{array}$ & $\begin{array}{l}\text { Number of rooms } \\
\text { that comply }\end{array}$ & $\begin{array}{l}\text { Percentage of rooms } \\
\text { that comply }(\%)\end{array}$ \\
\hline \multirow{3}{*}{$\begin{array}{l}\text { The room has a } \\
\text { daylight factor } \\
\text { more than } \\
1.5 \% / 2 \% / 1 \%{ }^{37,42^{*}}\end{array}$} & $\begin{array}{l}\text { living room } \\
(1.5 \%)\end{array}$ & 165 & 74 & 45 \\
\hline & kitchen (2\%) & 74 & 0 & 0 \\
\hline & $\mathrm{d}$ bed $(1 \%)$ & 158 & 69 & 44 \\
\hline \multirow{3}{*}{$\begin{array}{l}\text { The room depth is } \\
\text { not too large in } \\
\text { comparison with } \\
\text { the window height } \\
37\end{array}$} & living room & 137 & 100 & 73 \\
\hline & kitchen & 59 & 58 & 98 \\
\hline & $\mathrm{d}$ bed & 153 & 148 & 97 \\
\hline \multirow{6}{*}{$\begin{array}{l}\text { The room is } \\
\text { painted in a light } \\
\text { colour with a matt } \\
\text { finish } 46,43\end{array}$} & hall & 11 & 11 & 100 \\
\hline & living room & 165 & 154 & 93 \\
\hline & kitchen & 74 & 71 & 96 \\
\hline & $\mathrm{d}$ bed & 158 & 149 & 94 \\
\hline & s bed & 61 & 58 & 95 \\
\hline & bath & 14 & 13 & 93 \\
\hline
\end{tabular}

* Recommends "Kitchens must achieve a minimum average daylight factor of at least $2 \%$ " and "All living rooms... must achieve a minimum average daylight factor of at least $1.5 \% "$ 
Table 6 Average daylight factor - scheme Level

\begin{tabular}{|c|c|c|c|c|c|c|c|c|c|c|c|c|}
\hline \multirow[b]{3}{*}{$\begin{array}{l}\text { Scheme } \\
\text { No. }\end{array}$} & \multirow{2}{*}{\multicolumn{3}{|c|}{$\begin{array}{l}\text { Living Room } \\
\text { Average Daylight } \\
\text { Factor }\end{array}$}} & \multirow[b]{3}{*}{$\begin{array}{l}\text { Sample } \\
\text { Size }\end{array}$} & \multirow{2}{*}{\multicolumn{3}{|c|}{$\begin{array}{l}\text { Kitchen } \\
\text { Average Daylight } \\
\text { Factor }\end{array}$}} & \multirow[b]{3}{*}{$\begin{array}{l}\text { Sample } \\
\text { Size* }\end{array}$} & \multirow{2}{*}{\multicolumn{3}{|c|}{$\begin{array}{l}\text { Double Bedroom } \\
\text { Average Daylight } \\
\text { Factor }\end{array}$}} & \multirow[b]{3}{*}{$\begin{array}{l}\text { Sample } \\
\text { Size** }\end{array}$} \\
\hline & & & & & & & & & & & & \\
\hline & Median & Range & & & $\begin{array}{l}\text { Median } \\
\text { [single } \\
\text { value] }\end{array}$ & Range & & & Median & Range & & \\
\hline 1 & 0.8 & (0.7) & 1.1) & 8 & 0.4 & (0.3, & $0.6)$ & 8 & 0.6 & (0.4, & $0.8)$ & 8 \\
\hline 2 & 0.9 & (0.6, & 1.6) & 4 & - & - & - & - & 1.1 & $(0.8$ & 1.2) & 3 \\
\hline 3 & 1.4 & $(0.5$ & 1.9) & 9 & 0.7 & (0.4, & 1.4) & 3 & 1.1 & (0.5, & 1.3) & 9 \\
\hline 4 & 2.1 & $(1.5$, & $3.6)$ & 6 & 1.7 & (0.9, & 2.0) & 3 & 0.7 & (0.5, & $0.8)$ & 6 \\
\hline 5 & 1.7 & $(0.8$ & 4.6) & 10 & 1.1 & $(0.8$ & 1.2) & 4 & 1.4 & (0.5, & 1.8) & 10 \\
\hline 6 & 2.3 & (2.0, & 2.6) & 8 & 1.5 & (0.3, & 1.5) & 8 & 1.9 & $(1.3$ & 2.0) & 8 \\
\hline 7 & 0.9 & $(0.7$ & 1.3) & 7 & 0.6 & (0.4, & 0.7) & 3 & 0.8 & (0.4, & 2.2) & 7 \\
\hline 8 & 1.4 & (0.6, & 2.0) & 6 & 0.6 & $(0.5$ & 1.0) & 6 & 0.6 & $(0.3$ & $0.7)$ & 6 \\
\hline 9 & 1.5 & $(0.3$ & 2.0) & 7 & {$[0.6]$} & - & - & 1 & 0.8 & $(0.2$ & 1.1) & 7 \\
\hline 10 & 0.4 & $(0.3$ & 1.1) & 9 & 0.3 & $(0.3$ & $0.3)$ & 2 & 0.6 & (0.5, & $0.8)$ & 9 \\
\hline 11 & 3.8 & (2.9, & 4.7) & 8 & {$[0.4]$} & - & - & 1 & 1.3 & (0.6, & 1.5) & 8 \\
\hline 12 & 1.1 & (0.6, & 2.7) & 7 & 0.8 & (0.6, & 0.9) & 3 & 1.1 & $(0.3$ & 1.5) & 7 \\
\hline 13 & 2.6 & (1.9, & 2.9) & 7 & 0.8 & (0.6, & 1.0) & 2 & 1.4 & $(1.2$ & 1.8) & 7 \\
\hline 14 & 0.8 & (0.4, & 1.2) & 8 & 0.3 & (0.3, & 0.7) & 8 & 0.6 & $(0.2$ & 1.4) & 8 \\
\hline 15 & 1.5 & (0.7, & 1.9) & 7 & 0.5 & (0.5, & $0.6)$ & 2 & 1.0 & (0.5, & 1.1) & 7 \\
\hline 16 & 1.0 & (0.6, & 1.9) & 9 & 0.6 & (0.6, & 1.4) & 3 & 0.7 & $(0.2$ & 1.1) & 9 \\
\hline 17 & 1.5 & (0.7, & 2.4) & 7 & 1.3 & (0.5, & 1.4) & 7 & 0.7 & (0.3, & 1.8) & 7 \\
\hline 18 & 1.3 & (0.4, & 1.6) & 6 & {$[0.3]$} & - & - & 1 & - & - & - & - \\
\hline 19 & 1.1 & (0.4, & 2.7) & 8 & [0.4] & - & - & 1 & 1.4 & (0.9, & 2.5) & 8 \\
\hline 20 & 2.1 & (1.5, & 2.7) & 7 & 0.7 & (0.6, & $0.8)$ & 4 & 1.3 & (0.6, & 1.6) & 7 \\
\hline 21 & 1.4 & $(0.3$ & 1.6) & 7 & 0.9 & (0.7, & 0.9) & 3 & 0.7 & (0.6, & 0.9) & 7 \\
\hline 22 & 1.6 & (0.4, & 2.2) & 6 & {$[0.8]$} & - & - & 1 & 1.3 & (0.3, & 1.5) & 6 \\
\hline 23 & 1.7 & $(0.8$ & 1.8) & 4 & - & - & - & - & 1.8 & (0.9, & 2.0) & 4 \\
\hline
\end{tabular}

* Where kitchens were not clearly separated from living rooms by an internal wall, the combined kitchen and living room was treated as a single room, with the daylight factor scores incorporated into those for living rooms.

** In studio apartments, where the living room and bedroom were combined, daylight factor scores for combined living room/bedrooms were incorporated into those for living rooms. 
Table 7 Solar shading: Prevention of glare

\begin{tabular}{|c|c|c|c|c|}
\hline & & $\begin{array}{l}\text { Number of rooms } \\
\text { to which item } \\
\text { applicable }\end{array}$ & $\begin{array}{l}\text { Number of rooms } \\
\text { that comply }\end{array}$ & $\begin{array}{l}\text { Percentage of rooms } \\
\text { that comply (\%) }\end{array}$ \\
\hline \multirow{4}{*}{$\begin{array}{l}\text { There are internal } \\
\text { vertical/Venetian } \\
\text { blinds for S, E, W } \\
\text { facing windows } \\
46,43\end{array}$} & living room & 151 & 77 & 51 \\
\hline & kitchen & 55 & 35 & 64 \\
\hline & $\mathrm{d}$ bed & 134 & 74 & 55 \\
\hline & $s$ bed & 57 & 39 & 68 \\
\hline \multirow{4}{*}{$\begin{array}{l}\text { The internal blinds } \\
\text { fully cover the } \\
\text { window(s) }\end{array}$} & living room & 77 & 73 & 95 \\
\hline & kitchen & 35 & 35 & 100 \\
\hline & $\mathrm{d}$ bed & 74 & 74 & 100 \\
\hline & s bed & 39 & 39 & 100 \\
\hline
\end{tabular}

